\title{
Reasons to be proud
}

\author{
Richard Hurley features and debates editor
}

The BMJ

We have many reasons to be proud of the United Kingdom. For one, in a world first, our government ended discrimination in access to healthcare on the basis of wealth when it founded the NHS in 1948. Before that, if you were sick as well as poor you were doubly unfortunate.

Fast forward 68 years, however, and the NHS is buckling under unprecedented pressure, caught in a perfect storm of rising demand and financial constraint. On this both authors of this week's Head to Head debate about how we fund healthcare are agreed. Where they differ is in how pride in our health system might be restored (doi:10.1136/bmj.i5424).

Christopher Smallwood, an economist and former NHS trust chair, points to other funding models, specifically those in other European countries where approved insurance schemes top up a basic package of care provided by the state. The UK is now rich enough, he writes, to drop the NHS's founding principle of care free to everyone at the point of need. Instead we should be pragmatic: no one should be denied healthcare because they can't afford it, with the poorest people's insurance subsidised by everyone else.

This is anathema to David Wrigley, a GP and deputy chair of the BMA Council. Charging patients would introduce structural iniquity — and would spell the demise of the NHS — he says.

Tony Blair's government managed larger increases in funding. What might the current government's motives be for underfunding the NHS, he asks, when it can find huge sums for projects like high speed rail and Trident? (Listen to both authors in a podcast at http://bit.ly/2enHhOy.)
The late Peter Draper, an "anti-establishment" public health researcher and long time campaigner against private sector involvement in the NHS, might well have agreed. Before his recent death he blogged about "privatisation, cutting services, and closing hospitals, even though we are seriously 'underbedded' in comparison with many countries," as his obituary explains (doi:10.1136/bmj.i4865).

We should also have pride in the health professionals who work on behalf of NHS patients, including the many who come from outside the UK and remain unsure of their future, being told only that "Brexit means Brexit." The health secretary wants England to be "self sufficient" in doctors, promising up to 1500 extra medical school places from 2018. But our editorialist Chris McManus wants policy detail beyond " 1500 means 1500; 2018 means 2018" (doi:10.1136/bmj.i5480), and our Briefing points out the value to healthcare of international exchange of ideas and skills (doi:10.1136/bmj.i5488).

The NHS is not only the most equitable model of funding healthcare but also may be among the most efficient ways to deliver it, as the US Commonwealth Fund found (http://bit.ly/ $2 \mathrm{dNdAo2}$ ). Let's hope we can still be proud of it in another seven decades.

\section{Follow Richard Hurley on Twitter @rich_hurley}

Published by the BMJ Publishing Group Limited. For permission to use (where not already granted under a licence) please go to http://group.bmj.com/group/rights-licensing/ permissions 